\title{
PROVISION OF FERMENTATION PRODUCT FERTILIZER USING TYPES OF MICROORGANISM SOURCES AND DOSAGE ON GROWTH ELEPHANT GRASS PRODUCTION
}

\author{
${ }^{1}$ Nikmah A, ${ }^{2}$ F. Ridhana, ${ }^{3}$ Eliyin,,${ }^{4}$ Rusli, ${ }^{5}$ F. Ilma \\ 1,2,5 Program Study Animal Husbandry Faculty of Agriculture Universitas Gajah Putih Indonesia \\ ${ }^{3}$ Study Program of Management Plantation Coffee, Faculty of Agriculture, University of Gajah Putih, Indonesia \\ ${ }^{5}$ Study Program of Agribusiness, Faculty of Agriculture, University of Gajah Putih, Indonesia.
}

DOI: https://doi.org/10.51193/IJAER.2021.7111

\begin{abstract}
This study aims to determine the PROVISION OF FERMENTATION RESOURCES USING MICROORGANISM SOURCES and DOSAGE on GROWTH, ELEPHANT GRASS PRODUCTION, and to determine the interaction between the two factors. The design used was a randomized block design (RBD) with three replications. The results showed that the manure produced by the fermentation of microorganisms had a very significant effect on plant height at each cutting and the best treatment was fruit microorganisms, the number of shoots on cutting II and III and the best treatment was banana stem microorganisms, and perplot wet production on cutting I with the best treatment is Em4. The effect of manure dose has a very significant effect on plant height at each cut with the best result is treatment $11.25 \mathrm{~kg} /$ plot, the number of shoots at each cut and the best result is treatment $7.50 \mathrm{~kg} /$ plot, and wet yield per plot on cutting I with the best results influence the dose of $11.25 \mathrm{~kg} /$ plot. There was a very significant interaction with plant height and number of shoots on cutting III with the treatment of fruit microorganisms at a dose of $11.25 \mathrm{~kg} /$ plot and banana stem microorganisms at a dose of $7.50 \mathrm{~kg} /$ plot.
\end{abstract}

Keywords: Fermentation, Microorganisms, Elephant Grass

\section{INTRODUCTION}

The people of Central Aceh district, especially in fulfilling their daily needs, besides being farmers, many also raise livestock both on a large and small scale. To increase the yield of animal feed production, it takes several planting treatments (Unggul Grass), including cultivating elephant grass plants (Pennisetum purpureum L), in order to meet the needs of animal feed. 
Grass that is often planted is called forage or superior grass is a plant that is deliberately cultivated or maintained. It can be seen from the number of livestock population from 2010 to 2011, especially large livestock in Central Aceh Regency is increasing while the area of grazing is getting smaller, therefore it is recommended for people who have livestock to plant forage so that they can meet the need for feed for their livestock, many techniques so that the forage grows well and produces high production.

Elephant grass (Pennisetum purpureum L) is a superior type of grass, long-lived, grows vertically to form clumps, has dense leaves, and usually reaches a height of $2-2.5 \mathrm{~m}$. production - average around 250 tonnes / ha / year. This grass is good as a silage material, and as cutting grass and shepherds, as long as its growth can be maintained (Hartini, 1989).

Organic fertilizers include complete compound fertilizers because they contain more than one element and contain micro elements. When viewed from its shape, organic fertilizers can be divided into two, namely solid and liquid organic fertilizers. (Effiismawati, Musnawar 2003).

Many experts argue that microorganisms (EM) are not classified into fertilizers, EM is a material that helps accelerate the process of making organic fertilizers and improve their quality. In addition, EM also has the benefit of improving the structure and texture of the soil for the better, as well as supplying nutrients needed by plants. Therefore, the use of EM is useful for making plants more fertile, healthier, and relatively resistant to pests and diseases (Hadisuwito, Sukamto, 2012).

The amount of costs incurred by breeders to buy commercial EM4 to help the process of making organic fertilizers is an obstacle in the process of making organic matter. From this condition, I want to research the types of microorganisms that come from the materials that are around us and their dosage on the growth and production of elephant grass.

\section{RESEARCH METHODS}

\section{Location and Time of Research}

This research will be carried out in the Pegasing sub-district, Central Aceh Regency with an altitude of $1250 \mathrm{~m} /$ asl. This research will be conducted from 21 December 2012 to 18 June 2013.

\section{Materials and Tools}

The materials used in this study are manure derived from buffalo dung which has been fermented beforehand, this formation process uses three types of sources of microorganisms derived from 
commercial EM4 sold in the market, EM fruit from papaya that has been processed. rot and EM rotten banana stems in the manufacturing process can be seen in appendix 19,20.

\section{Research Methods}

This study used a randomized block design (RAK) which was arranged factually with two factors, each factor consisting of 3 levels / levels and repeated 3 times, namely the first factor was fermented manure (E) consisting of 3 levels: EM4 (E1), EM of fruits (E2), EM of banana stems (E3). The second factor is the dose of manure (D) consisting of 3 levels: 5 tonnes / ha (D1), 10 tonnes / ha (D2), 15 tonnes / ha (D3).

From 9 treatment combinations with 3 replications, the number of plots was 27 plots. With a plot size of $300 \mathrm{~cm} \times 250 \mathrm{~cm}$, a plot height of $20 \mathrm{~cm}$, a spacing of $60 \times 75 \mathrm{~cm}$ and a planting hole depth of $10 \mathrm{~cm}$. The arrangement of treatment combinations can be seen in table 3 .

Table 1: Combination of Treatment and Dosage of Fermented Manure

\begin{tabular}{ccccc}
\hline & \multirow{2}{*}{ No } & \multirow{2}{*}{$\begin{array}{c}\text { Mombination } \\
\text { Treatment }\end{array}$} & $\begin{array}{c}\text { Manure Result } \\
\text { of Permentation }\end{array}$ & \multicolumn{2}{c}{ Manure Dosage } \\
\cline { 4 - 5 } & & & Ha $^{-\mathbf{1}}$ & Per plot \\
\hline 1 & $\mathrm{E}_{1} \mathrm{D}_{1}$ & EM4 & 5 ton & $3,75 \mathrm{~kg}$ \\
2 & $\mathrm{E}_{1} \mathrm{D}_{2}$ & $\mathrm{EM} 4$ & 10 ton & $7,50 \mathrm{~kg}$ \\
3 & $\mathrm{E}_{1} \mathrm{D}_{3}$ & $\mathrm{EM} 4$ & 15 ton & $11,25 \mathrm{~kg}$ \\
\hline 4 & $\mathrm{E}_{2} \mathrm{D}_{1}$ & $\mathrm{EMB}$ & 5 ton & $3,75 \mathrm{~kg}$ \\
5 & $\mathrm{E}_{2} \mathrm{D}_{2}$ & $\mathrm{EMB}$ & 10 ton & $7,50 \mathrm{~kg}$ \\
6 & $\mathrm{E}_{2} \mathrm{D}_{3}$ & $\mathrm{EMB}$ & 15 ton & $11,25 \mathrm{~kg}$ \\
\hline 7 & $\mathrm{E}_{3} \mathrm{D}_{1}$ & $\mathrm{EMP}$ & 5 ton & $3,75 \mathrm{~kg}$ \\
8 & $\mathrm{E}_{3} \mathrm{D}_{2}$ & $\mathrm{EMP}$ & 10 ton & $7,50 \mathrm{~kg}$ \\
9 & $\mathrm{E}_{3} \mathrm{D}_{3}$ & $\mathrm{EMP}$ & 15 ton & $11,25 \mathrm{~kg}$ \\
\hline
\end{tabular}

The mathematical model used is a linear randomized block design model (Bangun, 1988).

\section{Research Implementation}

\subsection{Land Preparation}

The land is processed using a hoe as well as the soil is leveled and weeds and weeds are cleared, then 27 plots of treatment are made with a length of $300 \mathrm{~cm}$, a width of $250 \mathrm{~cm}$, a height of 20 $\mathrm{cm}$, the distance between the plots is $80 \mathrm{~cm}$, the distance between the replications is $100 \mathrm{~cm}$.

\subsection{Preparation of Seeds}


The seeds used in this study were Elephant Grass which came from farmers' gardens by selecting old and good stems by cutting 3 books from the stem.

\subsection{Fertilization}

Fertilizer used in this study is manure which has undergone a fermentation process using three types of microorganism sources given 3 days before planting by sprinkling it on the treatment plot and stirring it to combine the fertilizer with the soil according to the treatment dose.

\subsection{Planting of cuttings}

Planting is done by plugging the cuttings into the soil that has been prepared, one book is in the soil and two books are above the soil surface so that there are 16 cuttings per plot with a spacing of $60 \times 75 \mathrm{~cm}$, and at the age of 20 days after planting, the dead plants are inserted. .

\subsection{Maintenance}

Maintenance includes watering, pendangiran, weeding.

Watering is carried out if it does not rain, filtering and weeding are carried out to avoid disturbing plants or weeds that grow in the research area.

\subsection{Observations}

Observations were carried out randomly on 4 sample plants, the variables observed included plant height, number of shoots, wet production per plot as well as, elephant grass plant height was observed before cutting I, II and III, measured from the base of the stem to the tip of the plant shoots. subsequent measurements were measured after cutting and so on. The number of shoots was counted after cutting I, II and III by counting the number of shoots that grew. The wet production of elephant grass per plot is done by cutting leaving $5 \mathrm{~cm}$ from the ground at each cutting time I, II and III and weighing the wet weight of elephant grass per plot according to the time of cutting.

\section{RESULTS AND DISCUSSION}

\section{Effect of Manure from Fermentation of Microorganisms}

\subsection{Plant Height}

Table 1 shows that the plant height at cutting I, II and III for each treatment was significantly different. Em4 treatment was significantly different from fruit microorganisms, and both were significantly different from banana stem microorganisms at each cut. 
Volume: 07, Issue: 01 "January-February 2021"

This is because the response of mole microorganisms that have broken down to the soil of elephant grass plant growth with the environment, especially the adjustment of plant roots to the soil, and vegetative growth are closely related to the ability of plants to grow and develop according to Harjadi (1979), the ability to grow and develop is influenced by supporting environmental conditions such as soil, soil organic matter, soil organisms, soil atmosphere and ground water.

According to Schmidt (1994), the occurrence of changes in bacterial cells is a changing environmental factor, so that the development of Em4 microorganisms is disrupted and affects plant growth.

Table 2: Average Height of Elephant Grass (Pennisetum purpureum L) due to the application of manure for cutting I, II, and III.

\begin{tabular}{cc}
\hline & Plant height \\
\cline { 2 - 2 } Treatment & Deductions I \\
\hline E1 & $45.50 \mathrm{a}$ \\
E2 & $46.77 \mathrm{ab}$ \\
E3 & $48.31 \mathrm{c}$ \\
\hline BNT 0,05 & 1.35 \\
\hline & Deductions II \\
\hline E1 & $119.31 \mathrm{c}$ \\
E2 & $115.02 \mathrm{~b}$ \\
E3 & $103.05 \mathrm{a}$ \\
\hline BNT 0,05 & 3.28 \\
\hline & Deductions III \\
\hline E1 & $127.82 \mathrm{~b}$ \\
\hline E2 & $129.49 \mathrm{c}$ \\
\hline E3 & $124.49 \mathrm{a}$ \\
\hline BNT 0,05 & 1.92
\end{tabular}

Note: The numbers followed by the same letter in the same column are not significantly different at the 5\% LSD test level

\subsection{Number of Shoots}

Table 2 shows that in cutting I the number of shoots in EM4 treatment, fruit microorganisms and banana stem microorganisms were not significantly different. In cutting II and III, EM4 treatment was significantly different from fruit microorganisms, and fruit microorganisms were significantly different from banana stem microorganisms. 
The highest yield was found in the treatment of the effect of manure resulting from fermentation of banana stem microorganisms on cutting III, and the lowest yield was found in the treatment of the effect of manure from fermented banana stem microorganisms on cutting I. This is the initial stage of plant growth and development because it is influenced by the presence of tissue. meristems located at the tips of the roots and stems affect the number of shoots and roots grow lengthwise.

Musnawar (2002) states that Mol microorganisms will take longer to decompose with the soil. According to Anwar (1983), the point of growth and growth through shoots is at the point of growth in the form of a liquid which is a stem protector (celeoptil) on the root (keliorija) so that it affects the direction, as well as the buds to grow and develop.

Anonymous (1993) stated that nutrient uptake at the beginning of growth has not reached its maximum condition and it is called the slow vegetative phase of nutrients needed by elephant grass for growth which are not available because Mol microorganisms are still in the process of adapting to the environment.

Table 3: Average Number of Elephant Grass Shoots (Pennisetum purpureum L) at Cutting I, II, and III.

\begin{tabular}{cc}
\hline & Plant height \\
\cline { 2 - 2 } Treatment & Deductions I \\
\hline E1 & $7.07 \mathrm{a}$ \\
E2 & $7.00 \mathrm{a}$ \\
BNT 0,05 & $6.96 \mathrm{a}$ \\
\hline & - \\
\hline E1 & Deductions II \\
E2 & $30.34 \mathrm{a}$ \\
E3 & $32.34 \mathrm{~b}$ \\
\hline BNT 0,05 & $34.64 \mathrm{c}$ \\
\hline & 0.76 \\
\hline E1 & Deductions III \\
E2 & $141.74 \mathrm{a}$ \\
E3 & $148.85 \mathrm{~b}$ \\
\hline BNT 0,05 & $157.77 \mathrm{c}$ \\
\hline Note: The numbers & 2.33 \\
\hline
\end{tabular}

Note: The numbers followed by the same letter in the same column are not significantly different at the 5\% LSD test level. 


\subsection{Wet Production Perplot}

Table 3 shows that in cutting I the wet production per plot of EM4 treatment was significantly different from the treatment of fruit microorganisms and banana stem microorganisms, but they were not significantly different. In cutting II and III of EM4 treatment, fruit microorganisms and banana stem microorganisms were not significantly different. The highest yield was found in the treatment of the effect of manure from fermentation of EM4 microorganisms and the lowest was found in cutting I on the effect of manure from fermentation of microorganisms on the treatment of fruit microorganisms. It is assumed that the increasing number of roots that appear which affects the plant to obtain more nutrients which causes the vegetative growth of the plant to be more active.

Abidin (1984) states that production yields will increase if the soil aeration is in good condition and sufficient nutrients are available and the plant's ability to absorb the nutrients provided so that plant growth and development will be good and production results will be good too.

Table 4: Average wet production perplot of elephant grass (Pennisetum purpureum L) due to the application of manure for cutting I, II, and III.

\begin{tabular}{cc}
\hline & Production Wet/Plot(kg) \\
\cline { 2 - 2 } Treatment & Deductions I \\
\cline { 2 - 2 } E1 & $5,12 \mathrm{~b}$ \\
E2 & $4,33 \mathrm{a}$ \\
\hline BNT 0,05 & $4,61 \mathrm{ab}$ \\
\hline & 0,42 \\
\hline E1 & Deductions II \\
E2 & $21,00 \mathrm{a}$ \\
E3 & $20,00 \mathrm{a}$ \\
\hline BNT 0,05 & $18,00 \mathrm{a}$ \\
\hline & - \\
\hline E1 & Deductions III \\
E2 & $18,00 \mathrm{a}$ \\
E3 & $17,00 \mathrm{a}$ \\
BNT 0,05 & $16,00 \mathrm{a}$ \\
\hline
\end{tabular}

Note: The numbers followed by the same letter in the same column are not significantly different at the 5\% LSD test level. 


\section{Effect of Dose}

\subsection{Plant Height}

Table 4 shows that the plant height at cutting I, II and III for each treatment is significantly different. Treatment of $3.75 \mathrm{~kg} /$ plot was significantly different from treatment of $7.50 \mathrm{~kg} / \mathrm{plot}$, and both were significantly different from $11.25 \mathrm{~kg} /$ plot.

The highest yield was the effect of the dose of manure produced by fermentation of microorganisms in the treatment of $11.25 \mathrm{~kg} /$ cutting plot III, and the lowest yield was the effect of the dose of manure resulting from fermented microorganisms on treatment $3.75 \mathrm{~kg} / \mathrm{cutting}$ plot I. has been decomposed so that plant growth absorbs a lot of nutrients in the soil through the roots and the higher the $\mathrm{N}$ content in manure, the higher the elephant grass plant.

According to Sugeng (1992), growth will be good if the nutrients present in manure are given through the soil, the more the plant growth and yields will be better.

EM4, fruit microorganisms and banana stem microorganisms were not significantly different. The highest yield was found in the treatment of the effect of manure from fermentation of EM4 microorganisms and the lowest was found in cutting I on the effect of manure from fermentation of microorganisms on the treatment of fruit microorganisms. It is assumed that the increasing number of roots that appear which affects the plant to obtain more nutrients which causes the vegetative growth of the plant to be more active.

Abidin (1984) states that production yields will increase if the soil aeration is in good condition and sufficient nutrients are available and the plant's ability to absorb the nutrients provided so that plant growth and development will be good and production results will be good too. 
International Journal of Agriculture and Environmental Research

ISSN: 2455-6939

Volume: 07, Issue: 01 "January-February 2021"

Table 5: Average wet production perplot of elephant grass (Pennisetum purpureum L) due to the application of manure for cutting I, II, and III.

\begin{tabular}{cc}
\hline & Production Wet/Plot(kg) \\
\cline { 2 - 2 } Treatment & Deductions I \\
\cline { 2 - 2 } E1 & $5,12 \mathrm{~b}$ \\
E2 & $4,33 \mathrm{a}$ \\
E3 & $4,61 \mathrm{ab}$ \\
\hline BNT 0,05 & 0,42 \\
\hline & Deductions II \\
\hline E1 & $21,00 \mathrm{a}$ \\
E2 & $20,00 \mathrm{a}$ \\
E3 & $18,00 \mathrm{a}$ \\
\hline BNT 0,05 & - \\
\hline E1 & Deductions III \\
E2 & $18,00 \mathrm{a}$ \\
E3 & $17,00 \mathrm{a}$ \\
\hline
\end{tabular}

BNT 0,05

Note: The numbers followed by the same letter in the same column are not significantly different at the 5\% LSD test level.

\section{Effect of Dosage}

\subsection{Plant Height}

Table 5 shows that the plant height at cutting I, II and III for each treatment is significantly different. Treatment of $3.75 \mathrm{~kg} /$ plot was significantly different from treatment of $7.50 \mathrm{~kg} / \mathrm{plot}$, and both were significantly different from $11.25 \mathrm{~kg} /$ plot.

The highest yield was the effect of the dose of manure produced by fermentation of microorganisms in the treatment of $11.25 \mathrm{~kg} /$ cutting plot III, and the lowest yield was the effect of the dose of manure resulting from fermented microorganisms on treatment $3.75 \mathrm{~kg} /$ cutting plot I. has been decomposed so that plant growth absorbs a lot of nutrients in the soil through the roots and the higher the $\mathrm{N}$ content in manure, the higher the elephant grass plant.

According to Sugeng (1992), growth will be good if the nutrients present in manure are given through the soil, the more the plant growth and yields will be better. 
International Journal of Agriculture and Environmental Research

ISSN: 2455-6939

Volume: 07, Issue: 01 "January-February 2021"

Table 6: Average Height of Elephant Grass (Pennisetum purpureum L)

Due to Manure Dose at Mowing I, II, and III.

\begin{tabular}{cc}
\hline & Plant height \\
\cline { 2 - 2 } Treatment & Deductions I \\
\hline D1 & $45.94 \mathrm{a}$ \\
D2 & $48.55 \mathrm{c}$ \\
D3 & $46.08 \mathrm{ab}$ \\
\hline BNT 0,05 & 1.35 \\
\hline & Deductions II \\
\hline D1 & $107.54 \mathrm{a}$ \\
D2 & $111.10 \mathrm{~b}$ \\
D3 & $118.73 \mathrm{c}$ \\
\hline BNT 0,05 & 3.28 \\
\hline D1 & Deductions III \\
D2 & $128.05 \mathrm{~b}$ \\
D3 & $124.67 \mathrm{a}$ \\
\hline BNT 0,05 & $129.07 \mathrm{c}$ \\
\hline
\end{tabular}

Note: The numbers followed by the same letter in the same column are not significantly different at the 5\% LSD test level.

\subsection{Number of Shoots}

Table 6 shows that in cutting I and III, the number of shoots in treatment $3.75 \mathrm{~kg} /$ plot was significantly different from treatment $7.50 \mathrm{~kg} / \mathrm{plot}$, and $11.25 \mathrm{~kg} /$ plot, both were not significantly different. In cutting II treatment $3.75 \mathrm{~kg} /$ plot was significantly different from 7.50 $\mathrm{kg} /$ plot and $11.25 \mathrm{~kg} /$ plot, treatment $7.50 \mathrm{~kg} /$ plot was also different from $11.25 \mathrm{~kg} /$ plot.

The highest yield was found in the treatment of the effect of the dose of $7.50 \mathrm{~kg} /$ cutting plot III, and the lowest yield was the effect of manure resulting from fermentation of microorganisms on treatment $3.75 \mathrm{~kg} /$ cutting plot I. plant buds.

Local microorganisms (MOL) are microorganisms that are used as a starter in the manufacture of solid organic fertilizers or liquid fertilizers. The main ingredients of MOL consist of several components, namely carbohydrates, glucose, and a source of microorganisms. The basic ingredients for the fermentation of MOL solutions can come from agricultural, plantation, or household organic waste. Carbohydrates as a source of nutrition for microorganisms can be obtained from organic waste such as water washing rice, cassava, wheat, elephant grass, and 
Volume: 07, Issue: 01 "January-February 2021"

gamal leaves. Sources of glucose come from brown sugar, granulated sugar and coconut water, as well as sources of microorganisms from rotten fruit skins, shrimp paste, snails, stale rice, and cow urine (Hadinata, 2008).

Table 7: Average Number of Elephant Grass Shoots (Pennisetum purpureum L) Due to Manure Dose at Mowing I, II, and III.

\begin{tabular}{cc}
\hline & Number of Shoots \\
\cline { 2 - 2 } Treatment & Deductions I \\
\hline D1 & $6.58 \mathrm{a}$ \\
D2 & $7.24 \mathrm{~b}$ \\
D3 & $7.21 \mathrm{~b}$ \\
\hline BNT 0,05 & 0.21 \\
\hline & Deductions II \\
\hline D1 & $31.37 \mathrm{a}$ \\
D2 & $32.78 \mathrm{~b}$ \\
D3 & $33.17 \mathrm{c}$ \\
\hline BNT 0,05 & 0.76 \\
\hline & Deductions III \\
\hline D1 & $140.90 \mathrm{a}$ \\
D2 & $154.20 \mathrm{~b}$ \\
D3 & $153.26 \mathrm{~b}$ \\
\hline
\end{tabular}

BNT 0,05

2.33

Note: The numbers followed by the same letter in the same column are not significantly different at the 5\% LSD test level.

\subsection{Wet Production Perplot}

Table 7 shows that in cutting I, the wet production per treatment plot was $3.75 \mathrm{~kg} / \mathrm{plot}$ and $11.25 \mathrm{~kg} /$ plot were not significantly different, but both were significantly different from $7.50 \mathrm{~kg}$ / plot. In cutting II and III for each treatment was not significantly different. The highest yield was found in the treatment of $11.25 \mathrm{~kg} /$ plot of the effect of the dose of manure fermented microorganisms on cutting II, and the lowest yield was found in the treatment of $3.75 \mathrm{~kg} / \mathrm{plot}$ of the effect of the dose of manure fermented microorganisms on cutting I. This is presumed because The manure given to the D3 treatment of cutting II was more than in the D1 treatment of cutting I and the decomposition process had occurred for a very long time. 
Volume: 07, Issue: 01 "January-February 2021"

According to Novian (2005), the nitrogen element contained in manure has a role as a constituent of chlorophyll, protein and fat, besides stimulating vegetative growth such as increasing plant height, the number of shoots so that production results will also increase.

Table 8: Average Wet Production Perplot of Elephant Grass (Pennisetum purpureum L) Due to Dose of Manure in Cutting I, II, and III.

\begin{tabular}{cc}
\hline & Production Wet plot $(\mathrm{kg})$ \\
\cline { 2 - 2 } Treatment & Deductions I \\
\hline D1 & $4,27 \mathrm{a}$ \\
D2 & $5,07 \mathrm{~b}$ \\
D3 & $4,73 \mathrm{ab}$ \\
\hline BNT 0,05 & 0,42 \\
\hline & Deductions II \\
\hline D1 & $18,00 \mathrm{a}$ \\
D2 & $20,00 \mathrm{a}$ \\
D3 & $20,60 \mathrm{a}$ \\
\hline BNT 0,05 & - \\
\hline & Deductions III \\
\hline D1 & $17,00 \mathrm{a}$ \\
D2 & $18,00 \mathrm{a}$ \\
D3 & $17,00 \mathrm{a}$ \\
\hline
\end{tabular}

BNT 0,05

Note: Numbers followed by the same letter in the same column not significantly different at the $5 \%$ LSD test level.

\section{Effect of Interaction}

\subsection{Plant height}

Table 8 shows that the highest yield was found in the treatment of fruit microorganisms $11.25 \mathrm{~kg}$ / plot on cutting III and the lowest yield was found in EM4 treatment $11.25 \mathrm{~kg} /$ plot on cutting I. It is assumed that the role of moles in the soil is getting longer until in cutting III the decomposition process is higher.

The role of MOL in compost, apart from being a nutrient supplier, also acts as a bioreactor component which is responsible for maintaining the optimal growth process of plants. In addition, MOL has a function to loosen the soil, can replace fertilizers which are relatively more expensive, replace farmers' dependence on using inorganic fertilizers, increase production, 
Volume: 07, Issue: 01 "January-February 2021"

improve soil structure, reduce the cost of purchasing fertilizers, encourage farmers to provide fertilizer for their own needs without having to buy fertilizers. expensive (Christine, 2008).

Table 9: Average Height of Elephant Grass (Pennisetum purpureum L) due to the application of fermented manure and manure doses for cutting I, II, and III.

\begin{tabular}{|c|c|c|c|}
\hline \multirow{3}{*}{ Treatment } & \multicolumn{3}{|c|}{ Plant height } \\
\hline & \multicolumn{3}{|c|}{ Deductions I } \\
\hline & $\mathrm{D}_{1}$ & $\mathrm{D}_{2}$ & $\mathrm{D}_{3}$ \\
\hline$E_{1}$ & $48.16 \mathrm{~cd}$ & $48.55 \mathrm{~cd}$ & $39.80 \mathrm{a}$ \\
\hline $\mathrm{E}_{2}$ & $40.91 \mathrm{ab}$ & $51.91 \mathrm{~d}$ & 47.47 bc \\
\hline $\mathrm{E}_{3}$ & $48.75 \mathrm{~cd}$ & $54.19 \mathrm{~b}$ & $51.00 \mathrm{~d}$ \\
\hline \multirow[t]{3}{*}{ BNT 0,05} & & 4.09 & \\
\hline & \multicolumn{3}{|c|}{ Deductions II } \\
\hline & $\mathrm{D}_{1}$ & $\mathrm{D}_{2}$ & $\mathrm{D}_{3}$ \\
\hline $\mathrm{E}_{1}$ & $114.73 \mathrm{bc}$ & $123.47 \mathrm{cde}$ & 119.72 cde \\
\hline $\mathrm{E}_{2}$ & $103.41 \mathrm{~b}$ & $116.63 \mathrm{bc}$ & $125.00 \mathrm{e}$ \\
\hline$E_{3}$ & $104.47 \mathrm{bc}$ & $93.20 \mathrm{a}$ & $1115.48 \mathrm{bc}$ \\
\hline \multirow[t]{3}{*}{ BNT 0,05 } & & 9.94 & \\
\hline & \multicolumn{3}{|c|}{ Deductions III } \\
\hline & $\mathrm{D}_{1}$ & $\mathrm{D}_{2}$ & $\mathrm{D}_{3}$ \\
\hline $\mathrm{E}_{1}$ & $128.89 \mathrm{bcd}$ & $123.75 \mathrm{ab}$ & $130.83 \mathrm{~cd}$ \\
\hline $\mathrm{E}_{2}$ & $128.47 \mathrm{bcd}$ & $128.88 \mathrm{bcd}$ & $131.11 \mathrm{~d}$ \\
\hline $\mathrm{E}_{3}$ & $126.80 \mathrm{abcd}$ & $121.39 \mathrm{a}$ & $125.27 \mathrm{abc}$ \\
\hline BNT 0,05 & & 5.78 & \\
\hline
\end{tabular}

Note: Numbers followed by the same letter in the same column not significantly different at the $5 \%$ LSD test level.

\subsection{Number of Shoots}

Table 9 shows that the highest yield was found in banana stem microorganism treatment of 7.50 $\mathrm{kg} /$ plot in cutting III, and the lowest yield was found in banana stem microorganism treatment of $3.75 \mathrm{~kg} /$ plot on cutting I.

It is thought that the more manure doses are given and the more frequent cutting is done, it affects the number of shoots growing on Elephant Grass. 
Volume: 07, Issue: 01 "January-February 2021"

Sosrosoedirdjo (1982) argues that the organic forming material or fermenting organic matter in the cell will affect the growth of shoots, the more organic matter in the soil, the more buds that grow.

In addition, microorganisms can be applied as inoculants to increase the diversity and population of microorganisms in the soil and further improve plant health, growth and productivity. To increase soil fertility, the nutrients contained in it must be maintained or increased. One of the ways that can be done is by adding Mol solution (Anonymous, 2010).

Table 10: Average Number of Elephant Grass Shoots (Pennisetum purpureum L) due to the application of fermented manure and manure doses for cutting I, II, and III.

\begin{tabular}{|c|c|c|c|}
\hline \multirow{3}{*}{ Treatment } & \multicolumn{3}{|c|}{ Plant height } \\
\hline & \multicolumn{3}{|c|}{ Deductions I } \\
\hline & $\mathrm{D}_{1}$ & $\mathrm{D}_{2}$ & $\mathrm{D}_{3}$ \\
\hline $\mathrm{E}_{1}$ & $7.03 \mathrm{bcd}$ & $7.65 \mathrm{~cd}$ & $6.52 \mathrm{ab}$ \\
\hline $\mathrm{E}_{2}$ & $6.72 \mathrm{~b}$ & $6.99 \mathrm{bc}$ & $7.30 \mathrm{~cd}$ \\
\hline $\mathrm{E}_{3}$ & $6.00 \mathrm{a}$ & $7.06 \mathrm{bcd}$ & $7.82 \mathrm{~d}$ \\
\hline \multirow[t]{3}{*}{ BNT 0,05} & \multicolumn{3}{|c|}{0.67} \\
\hline & \multicolumn{3}{|c|}{ Deductions II } \\
\hline & $\mathrm{D}_{1}$ & $\mathrm{D}_{2}$ & $\mathrm{D}_{3}$ \\
\hline $\mathrm{E}_{1}$ & $30.63 \mathrm{ab}$ & $30.65 \mathrm{ab}$ & $29.72 \mathrm{a}$ \\
\hline $\mathrm{E}_{2}$ & $31.55 \mathrm{abc}$ & $32.78 \mathrm{bcd}$ & $32,71 \mathrm{bcd}$ \\
\hline $\mathrm{E}_{3}$ & $31.91 \mathrm{abc}$ & $34.91 \mathrm{~cd}$ & $37.11 \mathrm{~d}$ \\
\hline \multirow[t]{3}{*}{ BNT 0,05} & \multicolumn{3}{|c|}{2.28} \\
\hline & \multicolumn{3}{|c|}{ Deductions III } \\
\hline & $\mathrm{D}_{1}$ & $\mathrm{D}_{2}$ & $\mathrm{D}_{3}$ \\
\hline $\mathrm{E}_{1}$ & $131.95 \mathrm{a}$ & $142.81 \mathrm{bc}$ & $150.48 \mathrm{bcd}$ \\
\hline $\mathrm{E}_{2}$ & $141.39 \mathrm{~b}$ & 155.47 bcde & $149.70 \mathrm{bcd}$ \\
\hline $\mathrm{E}_{3}$ & $149.36 \mathrm{bcd}$ & $164.34 \mathrm{de}$ & $159.61 \mathrm{cde}$ \\
\hline
\end{tabular}

Note: Numbers followed by the same letter in the same column not significantly different at the 5\% LSD test level.

\section{CONCLUSION}

1. The treatment of the effect of manure resulting from fermentation of microorganisms has a very significant effect on plant height at each cutting and the best treatment is fruit 
International Journal of Agriculture and Environmental Research

ISSN: 2455-6939

Volume: 07, Issue: 01 "January-February 2021"

microorganisms, the number of shoots in cutting II and III and the best treatment is banana stem microorganisms, and wet yield per plot on cutting I with the best treatment is EM4.

2. The treatment of the effect of manure doses has a very significant effect on plant height at each cut with the best results on treatment $11.25 \mathrm{~kg} /$ plot, the number of shoots per cut and the best results of treatment $7.50 \mathrm{~kg} /$ plot, and the wet production per plot on cutting I the best effect dose was $11.25 \mathrm{~kg} /$ plot.

3. There was a very significant interaction with plant height and number of shoots on cutting III with fruit microorganisms treatment $11.25 \mathrm{~kg} /$ plot and banana stem microorganisms $7.50 \mathrm{~kg} /$ plot.

\section{REFERENCES}

1. Abidin, 1984. Dasar-dasar ilmu tanaman. Bandung. Angkasa, 177 halaman.

2. Anonymous, 1989. Budidaya pakan ternak.jakarta.Penebar swadaya, 110 halaman.

3. Anonymous, 1993. Mengapa kita harus makan sayur.BIP. Departemen Pertanian, 8 halaman.2008. Pedoman teknis perluasan areal hijauan makanan ternak.jakarta. PT LA A6, 25 halaman.

4. Anonymous 2010. Pedoman Budidaya Tanaman Kopi. Bandung. Nuansa aulia, 192 halaman.

5. Anwar, 1983. Anatomi tumbuhan liar. Jakarta. Gramedia, 45 halaman.

6. Asnaini S, 1979. Anatomi tanaman keras. Jakarta. Penebar swadaya,117 halaman

7. Bangun, M.K, 1988. Rancangan percobaan. Medan. Universitas sumatera utara, 99 halaman.

8. Christine,2008.Cara Membuat Mol Tapai.Dari http://clearwaste.blogspot.com/.Dikutip Tanggal 4 Januari 2013.

9. Diskanak, 2010. Data potensi padang rumput dan padang pengembalaan serta jumlah populasi ternak di Kabupaten Aceh Tengah. Takengon. Dinas Peternakan Dan Perikanan Kabupaten Aceh Tengah.

10. Hadinata, 2008.Membuat kompos. Jakarta. Rhineka Cipta, 120 halaman.

11. Hadisuwito,S, 2012. Membuat pupuk organik cair. Jakarta. Agro media pustaka, 74 halaman.

12. Hardjadi, 1979. Agronomi I, PT. Jakarta. Penebar swadaya, 112 halaman.

13. Hartini S, 1989. Budidaya pakan ternak.Yogyakarta. Yayasan kanisius, 26 halaman.

14. Indriani, Y.H, 2003. Membuat kompos secara kilat. Jakarta. Penebar swadaya, 63 halaman.

15. Lingga, P. dan Marsono, 2010. Petunjuk penggunaan pupuk. Jakarta. Penebar swadaya, 72 halaman. 
16. Moloney, 1986. The Effect of Phosphorous and Nitrogen Application on The Early Growth of Adeantera payopiana, Albizia falcataria and Schleinetzia insularium. Hawai, Nitrogen Fixing Tree Association.

17. Mulyani dan kartasapoetra, 2005. Pengantar ilmu tanah. Jakarta. Rineka cipta, 10 halaman.

18. Musnawar, 2002.Hormon pada tanaman. Jakarta. Gramedia, 100 halaman.

19. Effiismawati,Musnawar, 2003. Pupuk organik cair, padat, pembuatan, aplikasi. Jakarta. Penebar swadaya, 72 halaman.

20. Novian, 2005. Biologi Tanaman. Jakarta. PT Bhineka Cipta, 61 halaman.

21. Novizan, 2002.Petunjuk pemupukan yang efektif.Tanggerang.Agro media pustaka, 35 halaman.

22. Rukmana, R,2005. Rumput unggul hijauan makanan ternak. Jakarta. Kanisius, 70 halaman.

23. Samekto, R, 2006. Pupuk kompos. Yogyakarta. PT Citra Ai Parama, 38 halaman.

24. Schmidt,K, 1994. Mikrobiologi umum.yogyakarta. Gajah mada university press, 117 halaman.

25. Sosrosoedirdjo, 1982. Fisiologi dan anatomi tanaman. Jakarta. Penebar swadaya, 30 halaman.

26. Sugeng, H. A, 1992. Bercocok tanam sayur-sayuran. Semarang. Aneka ilmu, 317 halaman.

27. Sumarsih, 2003. Mikrobiologi dasar.Yogyakarta. Jurusan Ilmu Tanah Fakultas Pertanian UPN, 24 halaman.

28. Suriatna, P, 1970. Budidaya rumput gajah. Jakarta. Karya barata, 30 halaman.

29. Sutanto, R, 2006. Penerapan pertanian organik. Yogyakarta. Kanisius, 43 halaman

30. Widodo, A.S, 1999. Ransum makanan kerbau. Bandung. Agro media tama, 70 halaman.

31. Wijaya, 1989.Budidaya rumput-rumputan untuk pakan ternak. Jakarta. Penebar swadaya, 30 halaman. 